\title{
Social Environmental Disclosure Between Gri-Sustainability Reporting and IIRC - Integrated Reporting Among European Companies
}

\author{
Suzila Mohamed Yusof ${ }^{1}$ \\ ${ }^{1}$ Faculty of Economics and Business, Universiti Malaysia Sarawak, Malaysia \\ Correspondence: Suzila Mohamed Yusof, Department of Accountancy, Faculty of Economics and Business, \\ Universiti Malaysia Sarawak, 94300 Kota Samarahan, Sarawak, Malaysia.
}

Received: March 12, 2018

doi:10.5539/ibr.v11n6p185

\author{
Accepted: May 17, $2018 \quad$ Online Published: May 25, 2018 \\ URL: https://doi.org/10.5539/ibr.v11n6p185
}

\begin{abstract}
This critical approach study examines the social and environmental disclosure (SED) between Sustainability Reporting (SR) and Integrated Reporting (IR) among European companies. This paper argues that IR abandons sustainability and might overlap with the functions of SR. The research questions are to examine the integration level of SED within SR and IR and look for the patterns and motifs from reviewing both reports. Applying the critical text analysis method, the GRI G3 guidelines were used to examine a sample of ten European companies. This method is applicable as it does not have rigid procedures to follow (Merkl-Davies et al., 2013). The reports for the selected companies must incorporate fully applied IR without producing any more SR in order to analyse the validity of the data. This study has discovered that there is less integration of SED in IR than SR. The analyses continued by reading and reviewing all reports to identify patterns and motifs. Company strategy and regulatory requirements, reporting style, the crucial issues of the materiality and the development of new sections in the reports were all explored. It is apparent that the IR approach is more towards the primary groups (investors) rather than other stakeholders, society and the environment as a whole. Hence, IR is only a mirror of sustainability for business strategy. Therefore, IR needs to engage reports with other stakeholders to sustain long-term growth.
\end{abstract}

Keywords: social and environmental disclosure, sustainability reporting, integrated reporting, global reporting initiative, IIRC

\section{Introduction}

\subsection{Research Background and Motivation}

Reporting on sustainability has developed significantly in the past three decades (Stubbs and Higgins, 2014). Especially in the recent ten years, there has been a momentous rise in SR amongst large multinational companies (Kolk, 2010). SR creates SED and brings great improvement of the quality of reports focusing on the Triple Bottom Line (TBL); social, environmental and financial disclosure (Bebbington, Unerman and O'Dwyer, 2014). There are, additionally, worries that SR may have been 'caught' by organisations trying to increase hegemonic power (accaglobal, 2012). The conviction that the preparation of corporate reporting on sustainability resulted from an exploration in social and environmental reporting can possibly effect on and transform corporate conduct (Bebbington and Gray, 2001). However, this sentiment usually may unable to achieve (Bebbington and Gray, 2001). Notwithstanding the important and late development in SR, the most recent confirmation concluded that almost all the world's largest 250 companies report on Corporate Responsibility (CR) and that 'Reporting is now the norm across all these sectors, with at least 62 percent of companies in every sector producing a CR report' (GRI, 2015). This shows that the practice of corporate sustainability disclosure has increased dramatically as the GRI produces according to stakeholder demand and raises awareness of the potential of disclosure towards organisation goals.

SED brings new channels of communication to influence the public. Through filling of the legitimacy gap (Archel et al., 2009) and increase legitimacy gap (Bouten et al.2011), SED delivers a positive image to companies and expands financial reporting (Bebbington, Unerman and O'Dwyer, 2014). Types of the disclosure include parts of annual reports, stand-alone reports, press releases and corporate websites (Bebbington, Unerman 
and O'Dwyer, 2014). Companies attempt to convince society that they have stakeholders' interest at heart and that they share common goals by using SED in social and environmental reporting as legitimising mechanism of companies to its stakeholders (Deegan et al., 2000; Deegan, 2002, 2007; and Mathews, 2004).

Development of SED has been influenced by the arrival of IR in 2010. IR contains about organization's plan, governance, performance and prospects in a brief delivery report, for its external environment through the value creation for short, medium and long-term (IIRC, 2013). IR merges SED and financial reports in a single report (de Villiers et al, 2014).

\section{Literature Review}

\subsection{Social Environmental Disclosures (SED)}

SED practices are intended to legitimise business organisations and develop strategies of legitimating (Archel et al., 2009). The existence of SED is explained by the emergence of legitimacy theory (LT) on the interaction between social value and acceptable behaviour of organisations (Dowling and Pfeffer, 1975). LT is defined by de Aguiar and Bebbington (2014) as a strategic way for an organisation to disclose good news and convince stakeholders to repair damaged legitimacy using certain legitimacy strategies. For example, SED has been used as a legitimating purpose in the CEO statements of SR. Despite expanding the standardisation of SR, the statements pinpoint management impression rather than accountability (Barkemeyer et al., 2014). The degree to which corporate SR serves as a reasonable representation of corporate sustainability-related performance involves drawing a similarity with financial reporting (Barkemeyer et al., 2014). Patten (2014) suggests that, in order to make SED a corporate legitimacy, it should become a tool of the public interest in the form of stand-alone reports rather than mandatory reports.

SED helps to manipulate social perceptions of environmental aspects by showing consistent beliefs and contributions (de Aguiar and Bebbington, 2014). However, according to Patten (2014), the practices of SED do not form the main agenda for obtaining high profit levels, as SED is more concerned with nurturing the image of environmental concern rather than catering for environmental actions. Additionally, environmental reporting has been developed to 'thicken the veil' (Patten, 2014, p. 201), covering environmental impact rather than transparency for the public interest.

According to the findings of Lu and Abeysekera (2014, p. 426), corporate SED has positive connections with firm size, profitability and industry classification. As suggested by numerous studies, other factors considered to be determinants of SED are organisational practice, participation among the pressure groups and media profile (Gray et al., 2001).

\subsection{GRI Guidelines}

Of all the standards that are available, the GRI guidelines are the most influential guidelines adopted by various organisations in preparing SR (Gomes et al., 2015), aiming to establish a generally accepted framework (Bebbington et al., 2014). The GRI guidelines target on the TBL by analysing information that is applicable and material to organisations for stakeholder's interest (GRI, 2013). The analysis finds that 78 percent of the best 100 organizations within 41 nations and 82 percent of the highest ranking within 250 organizations from the Global Fortune 500 use these guidelines (Gomes et al., 2015).

GRI was established in 1997 and the guidelines have been formally published since 2000 by the Coalition for Environmentally Responsible Economies (CERES) and the United Nations Environmental Programme (UNEP) (Isaksson and Steimle, 2009). The significant operator embedded within GRI guidelines enhances the quality of SR (Kolk and Perego, 2010; Perego and Kolk, 2012) and engaging most stakeholders, including the community and environment (Gray et al., 2014).

\subsection{Sustainability Reporting $(S R)$}

SR focuses on much wider attention and is intended to inform several different groups of stakeholders (Busco et al., 2013). As pointed out above, this challenges the usefulness of SR and stresses the role of materiality as to prioritize the needs of all stakeholders. SR is voluntary, with the exception of some countries, and exists in the context of a continuingly evolving situation (Busco et al., 2013). As with most widely employed standards for disclosure, the scope of SR goes beyond the legal entity and the assurance level is low, in the sense that non-financial information is more challenging to assure compared to financial information (Busco et al., 2013).

Lodhia (2014) has highlighted that SR is a new strand of accounting and a relatively new phenomenon which recognises social and environmental issues as critical and needs to be communicated effectively to stakeholders. The benchmark to measure a sustainable society can be divided into 'strong' and 'weak' criteria (Monfreda et al., 
2004). Strong sustainability assumes that natural capital irreplaceable and essential for example air and water; whilst weak sustainability builds when assets total is preserved within the human well-being (Monfreda et al., 2004). In terms of natural capital, it is very difficult to maintain rather than weak sustainability as when environmental and ecological services being destroyed, technology may be capable of restoring it (Monfreda et al., 2004).

Strong sustainability can be related with the environmental impacts. The analysis of the banks past reports by Lodhia (2014) indicates that it defines its environmental risks as both direct and indirect (Lodhia, 2014). Direct environmental risks include the usage of the natural resource, emissions and waste generation, whilst indirect environmental risks occur through the financial products and services offered, suppliers and partnerships (Lodhia, 2014).

\subsection{Integrated Reporting (IR)}

The existence of IIRC in developing practice and policy within IR has been recognised globally (De Villers et al., 2013). However, IIRC was not the pioneer in this area as IR's guidelines have been introduced in South Africa when IIRC not yet existed(Cheng et al., 2014). IIRC introduces a pilot program that monitors the implementation of IR whereby the early implementation exists during the period between 2009 to 2012 (Ioana \& Adriana, 2013). The pilot program offers to companies to demonstrate global leadership in the field of corporate reporting (unepfi.org). It involves companies as well as investors with the support of IIRC and peer group feedback from other participants (unepfi.org). The intention of the pilot program is to develop a new global standard in IR and aims to demonstrate the connection between organization's plan, financial achievement, governance, social, environmental and economic matter(unepfi.org).IR objectives to furnish a concise report that demonstrates an organisation's social, environmental and economic actions, risks, outcomes and opportunities to reflect the integration of an organisation in terms of measurement and management (de Villiers et al., 2014).

\subsection{Differences between $S R$ and $I R$}

The difference between SR and IR can be distinguished by the capital terms. As for IR, the IIRC states that only capitals that are important and relevant to the organizations to be classified as capitals (IIRC, 2013), thus allowing for a fix application of the framework. However, Busco et al (2013) argue that IR is not able to measure the stocks for the six capitals and their variations (flows). For some capitals, IR only measures some specific aspects, employing such indicators as a proxy for the whole capital (Busco et al., 2013). Clearly, outcomes are much more difficult to measure; this may be a further evolution and one of the main challenges IR will have to face (Busco et al., 2013). While IR takes into account the measurement (in terms of stock and flow) of capitals, which have clear similarities with balance sheets and income statements respectively, SRs report on the impacts of company activities (Busco et al., 2013). Conversely, SRs, the approach of natural capital (Monfreda et al., 2004) is significant in the reports concerning the environment impacts either direct or indirect impacts (Lodhia, 2014).

Table 1. Comparison between SR and IR

\begin{tabular}{lcc}
\hline Components & Sustainability Reporting (SR) & Integrated Reporting (IR) \\
\hline $\begin{array}{l}\text { Primary Audience } \\
\text { Main Focus }\end{array}$ & Stakeholders & $\begin{array}{c}\text { Shareholders } \\
\text { Perspectives }\end{array}$ \\
$\begin{array}{l}\text { Capitals } \\
\text { Material Principle }\end{array}$ & Backward -Looking & $\begin{array}{c}\text { Natural Capital } \\
\text { Value Creation -short, medium } \\
\text { and long-term } \\
\text { Forward Looking } \\
\text { Multiple Capitals }\end{array}$ \\
& $-\begin{array}{c}\text { Organisation significant impacts: social, } \\
\text { environmental and economic or } \\
\text { Control elements for decision-making and } \\
\text { stakeholders' assessment }\end{array}$ & $\begin{array}{c}\text { Organisations capability to create } \\
\text { value by changing the assessments } \\
\text { of financial capital providers }\end{array}$ \\
\hline
\end{tabular}

\section{Research Methodology}

\subsection{Method Selection}

This study adopts a primarily interpretative or critical approach to analyse the content of SR and, immediately, the introduction of IR. In this approach, there are three forms of textual analysis to be distirenguished (Merkl-Davies et al., 2011), starting with the scientific analysis involved in the positivist search methodological approach; for example, calculating sentences, words, coding and paragraphs and moving to 'interpretative text analysis' and 'critical text analysis' (Merkl-Davies et al., 2011). As both Global Reporting (GRI) - SR and IIRC - IR represent significant SED, this study compares the results from conducting critical text analysis and measuring the extent of reporting. Specifically, as critical text analysis approach does not adopt positive 
scientific research, it does not abide by fix arrangement of procedures (Merkl-Davies et al., 2011).

\subsection{Research Questions and Design}

This study aims to answer the research questions as below:

Research Question 1: How does the measurement of integration of SED, moving from SR to IR?

Research Question 2: What are the patterns and motifs that exist in the introduction of IR compared to SR?

Both research questions will involve two aspects of research. First, this study aims to measure the integration level of SED between SR and IR. Second, the study discusses the patterns and motifs in the process of reviewing all both reports pertaining to social and environmental consideration.

The following factors contribute to this: the gathering of data from small samples is applicable as generalisation in order to show the population (Fairclough, 2003). In order to respond to the purpose of the study, small samples can be analysed to find distinctive research perspectives (Fairclough 2003). Moreover, the demand of quasi-scientific codings is not applicable in social constructivist to textual analysis (Merkl-Davies et al., 2011). However, the analysis depends on the researcher itself on the measurement approach (Merkl-Davies et al., 2011).

Analysis of SR and IR is undertaken by deep reading and reviewing the reports of ten selected companies, interpretatively taking out elements of social and environmental information. The content of SED in the reports was analysed using a simple measurement.

The first measurement was of the integration level of SED between SR and IR. Instead of measuring using simple calculation, it highlights the development of SED in reports and checkups the spread/scope of SED throughout the reports. The process of measurement is being executed by considering the sections of each report that reported on social and environmental information, for example, the chairman's statement, risk management, corporate governance review and business review. This process is being done to escape positivist counting of 'mentions' or sentences or paragraphs. However, it generates an image of analysis by an adequate link between the social and environmental information and therefore, integration between them can be effectively recognised. This measurement adopts the GRI G3 guidelines as indicators to evaluate the results. In the analysis, measurement of SED is being done when the positive relationship occurred between the total number of elements and the integration level. When the total number of elements is increasing, it shows that the integration level is also the same. Eventually, using the approach undertaken in the analysis, several measurements have been calculated as follows:

- Accumulation difference overtime (ADOT) measures the total change (expand/diminish) in the number of sections in the reports reviewed where each element of social and environmental information appears.

- Proportion of positive difference of a number of sections measures the proportion of elements in each category (social and environmental) that are reported in an increased number of sections over the period.

- Proportion of positive and no difference of a number of sections measure the proportion of elements in each category (social and environmental) that are reported in an increased and no change in number of sections over the period.

Subsequently, in order to draw out a range of patterns and motifs, methods of interpretative and critical textual analyses of the report are beneficial. These patterns and motifs develop through the interpretative analysis by deep reading and reviewing all the reports. Through the deep reading and reviewing, the analysis detected any changes of image, figures and information as it became integrated.

\subsection{Sample Selection}

Ten samples of ten companies are relevant in this research, representing high social and environmental impact. As this research focuses on European companies, these selected companies have been chosen with the condition that the companies must have fully implemented IR without producing any more SR. Although most European companies have established sustainability in their businesses, the analysis undertaken by the IIRC (integratedreporting.org) indicates that only ten percent of companies have disclosed non-financial information in their reports. This shows that there is still a lack of reporting disclosures engaging in the reports. 
Table 2. Summary of Samples of the Companies

\begin{tabular}{llll}
\hline Company & Industry & Year of SR & Year of IR \\
\hline Deutsche Borse Group & Construction Services & 2011 & 2012 \\
ENBW & Electricity Energy & 2011 & 2012 \\
Grupa Lotos, Poland & Oil and Gas & 2008 & 2009 \\
Indra Spain & Telecommunication & 2007 & 2008 \\
Melia Hotel International & Tourism & 2012 & 2013 \\
Munich Airport & Transportation & 2009 & 2010 \\
Novo Nordisk, Denmark & Healthcare & 2003 & 2004 \\
Royal BAM Group & Construction Services & 2013 & 2014 \\
Royal DSM & Life and material sciences & 2009 & 2010 \\
Uralsib & Financial Services & 2010 & 2011 \\
\hline
\end{tabular}

\section{Results and Analysis}

\subsection{Measuring the Integration Level}

\subsubsection{Interpretation of Findings: Measuring the Integration Level}

Table 3 concludes the total ADOT score for each company in terms of social and environmental aspects, including the proportion positive difference and the proportion positive and no difference in the social and environment sections. In terms of the ADOT of the social aspect, this has shown that only three of ten companies increased disclosure in IR. Most of the companies disclosed around 70 percent fewer elements of social aspect in IR. On the other hand, ADOT for the environmental aspect showed that only four companies increased their environmental disclosure and only one company had no change in environmental disclosure. A justification for the lower score is because most companies have just introduced IR as new reporting and are still trying to adopt IR. Furthermore, the reports were combined with financial information and therefore, companies tried to balance between financial and sustainability/non-financial information.

In addition, the table shows that the proportion of the positive difference in social elements ranges from 0 percent to 48 percent. The justification of these results presents that companies responded to social issues for more than half of the report content instead of limiting the reporting to financial information. However, the social content represents minor parts of the report instead of other elements such as risk and governance, financial and business scopes. In the aspect of environmental information, the measures range from 0 percent to 43 percent of elements, showing a positive difference in the number of sections where they are presented. This scenario is similar to social elements as the range incurred is almost the same. The percentage shows that fewer environmental elements are reported and disclosed in IR. It seems that companies focused on other sections during the integration as more information needs to be disclosed in one particular report. This study also shows the percentage of elements in the number of sections for positive and no difference, where the interpretation further indicates the deficiency of negative change: in very few scenarios, SED were disclosed in fewer sections as IR has been introduced.

Based on the analyses undertaken, a few patterns and motifs arose: company strategy and regulatory requirements, reporting style, the crucial issues of materiality and the development of new sections in the reports. 
Table 3. Summary of the sample companies measuring the integration level

\begin{tabular}{|c|c|c|c|c|}
\hline Company & Type of Industry & & Social Aspect & $\begin{array}{c}\text { Environment } \\
\text { Aspect }\end{array}$ \\
\hline \multirow[t]{3}{*}{ Deutsche Borse Group } & \multirow[t]{3}{*}{ Construction Services } & Total ADOT & +18 & 0 \\
\hline & & $\begin{array}{l}\text { Proportion of positive difference } \\
\text { in number of section }\end{array}$ & $48 \%$ & $40 \%$ \\
\hline & & $\begin{array}{l}\text { Proportion of positive and no } \\
\text { difference in number of section }\end{array}$ & $88 \%$ & $77 \%$ \\
\hline \multirow{3}{*}{ ENBW } & \multirow{3}{*}{ Electricity Energy } & Total ADOT & -20 & -22 \\
\hline & & $\begin{array}{l}\text { Proportion of positive difference } \\
\text { in number of section }\end{array}$ & $10 \%$ & $0 \%$ \\
\hline & & $\begin{array}{l}\text { Proportion of positive and no } \\
\text { difference in number of section }\end{array}$ & $65 \%$ & $50 \%$ \\
\hline \multirow[t]{3}{*}{ GrupaLotos } & \multirow[t]{3}{*}{ Oil and Gas } & Total ADOT & -11 & -1 \\
\hline & & $\begin{array}{l}\text { Proportion of positive difference } \\
\text { in number of section }\end{array}$ & $0 \%$ & $3 \%$ \\
\hline & & $\begin{array}{l}\text { Proportion of positive and no } \\
\text { difference in number of section }\end{array}$ & $73 \%$ & $93 \%$ \\
\hline \multirow[t]{3}{*}{ Indra } & \multirow[t]{3}{*}{ Telecommunications } & Total ADOT & -7 & -14 \\
\hline & & $\begin{array}{l}\text { Proportion of positive difference } \\
\text { in number of section }\end{array}$ & $18 \%$ & $30 \%$ \\
\hline & & $\begin{array}{l}\text { Proportion of positive and no } \\
\text { difference in number of section }\end{array}$ & $85 \%$ & $87 \%$ \\
\hline \multirow{3}{*}{$\begin{array}{l}\text { Melia } \\
\text { International }\end{array}$} & \multirow[t]{3}{*}{ Tourism } & Total ADOT & -25 & -17 \\
\hline & & $\begin{array}{l}\text { Proportion of positive difference } \\
\text { in number of section }\end{array}$ & $5 \%$ & $20 \%$ \\
\hline & & $\begin{array}{l}\text { Proportion of positive and no } \\
\text { difference in number of section }\end{array}$ & $60 \%$ & $47 \%$ \\
\hline \multirow[t]{3}{*}{ Munich Airport } & \multirow[t]{3}{*}{ Transportation } & Total ADOT & +6 & +14 \\
\hline & & $\begin{array}{l}\text { Proportion of positive difference } \\
\text { in number of section }\end{array}$ & $43 \%$ & $23 \%$ \\
\hline & & $\begin{array}{l}\text { Proportion of positive and no } \\
\text { difference in number of section }\end{array}$ & $78 \%$ & $77 \%$ \\
\hline \multirow[t]{3}{*}{ Novo Nordisk } & \multirow[t]{3}{*}{ Healthcare } & Total ADOT & -1 & +2 \\
\hline & & $\begin{array}{l}\text { Proportion of positive difference } \\
\text { in number of section }\end{array}$ & $10 \%$ & $10 \%$ \\
\hline & & $\begin{array}{l}\text { Proportion of positive and no } \\
\text { difference in number of section }\end{array}$ & $70 \%$ & $97 \%$ \\
\hline \multirow[t]{3}{*}{ Royal BAM } & \multirow[t]{3}{*}{ Construction Services } & Total ADOT & +1 & +36 \\
\hline & & $\begin{array}{l}\text { Proportion of positive difference } \\
\text { in number of section }\end{array}$ & $13 \%$ & $43 \%$ \\
\hline & & $\begin{array}{l}\text { Proportion of positive and no } \\
\text { difference in number of section }\end{array}$ & $80 \%$ & $100 \%$ \\
\hline \multirow[t]{3}{*}{ Royal DSM } & $\begin{array}{l}\text { Life and Material } \\
\text { Sciences }\end{array}$ & Total ADOT & -9 & +2 \\
\hline & & $\begin{array}{l}\text { Proportion of positive difference } \\
\text { in number of section }\end{array}$ & $10 \%$ & $23 \%$ \\
\hline & & $\begin{array}{l}\text { Proportion of positive and no } \\
\text { difference in number of section }\end{array}$ & $50 \%$ & $87 \%$ \\
\hline \multirow[t]{3}{*}{ Uralsib } & \multirow[t]{3}{*}{ Financial Services } & Total ADOT & -28 & -11 \\
\hline & & $\begin{array}{l}\text { Proportion of positive difference } \\
\text { in number of section }\end{array}$ & $0 \%$ & $0 \%$ \\
\hline & & $\begin{array}{l}\text { Proportion of positive and no } \\
\text { difference in number of section }\end{array}$ & $58 \%$ & $63 \%$ \\
\hline
\end{tabular}

\subsection{Company Strategy and Regulatory Requirements}

The process of deep reading and reviewing all the reports showed that reporting for the scope of social and environmental issues is driven predominantly by company strategy and regulatory requirements. These results corroborate the ideas of Bouten et al. (2009) and Archel et al. (2009), who suggested that SED increases legitimacy and regulation intervention. This can be seen in the analysis, undertaken in line with CSR (corporate social responsibility) and company strategy (Grupa Lotos Group).

In terms of company strategy, for example in Deutsche Borse Group, the implementation of integrated reporting is driven by company strategy. The following CEO letter (Deutsche, 2012, p. 14) states that:

We are supporting a large number of initiatives to promote sustainability: We place particularly high value on 
our membership of the United Nations Global Compact and the implementation of its principles regarding human rights, labour, the environment and anti-corruption. After focusing strongly on our own sustainability performance and reporting in the past, which was again rewarded by our inclusion in key sustainability indices in 2012, we are now turning our attention to fostering transparency for holistic investment strategies on the global capital markets.

However, as most companies move on to IR, the application of the GRI guidelines is still applicable in the report. Some companies literally acknowledged the adoption of the GRI guidelines or other guidelines such as the TBL Indicator or the Accountability Standard AA1000. For example, Novo Nordisk's IR year 2004 states on page 58 that:

Novo Nordisk reports - and has done so since 2002 - in accordance with The Global Reporting Initiative's (GRI's) 2002 Sustainability Reporting Guidelines. The Guidelines require reporting in accordance with 11 principles and against a list of 97 sustainability performance indicators, of which 50 are core indicators that must be reported on. On the website is a GRI index with an overview of the full 'in accordance' reporting.

This is also similar to the case of Melia Hotel, when their first IR was introduced:

'This first Integrated Report on Meliá Hotel International is intended to comply with the core idea of the most innovative international standards: to report on the relevant information for the stakeholder groups' (Melia Hotel, p. 11).

Interestingly, in the case of Novo Nordisk, business strategy for the short and long-term looks forward to the diabetes care programme. Most topics in Novo Nordisk reported the issues of diabetes in terms of prospects and interviews with diabetes patients. The result of this report is similar to the case of Islam and Deegan (2010), which mentions that topics that received greater amounts of negative media coverage affect the corporation but that reaction involved provision of positive disclosure on the topics. Although both results are different in terms of topics, the greater coverage of Novo Nordisk had a significant impact on the readers of the report, encouraging them to be aware of the importance of curing diabetes patients.

\subsection{Reporting Style}

For Royal DSM, the use of images for IR brings a new scope of SED (Royal DSM, 2010 pp. 16-27). This result can be justified by the fact that images explain people, community, health and environment, showing that stakeholders create value for companies, aligning with the purpose of IR. A previous study undertaken by Duff (2011) on evaluating images observed inconsistent results on whether images are portrayed as producing value for clients and society. The analysis done by Duff (2011) classifies the insufficiency of gender and race in the annual reviews. Duff (2011) finds that the job functions and locations represented inequality and stereotyping even though the annual reviews show the firm's build value for its clients and society. These findings may help to understand that images give significant indicators to the readers on how well the companies are doing at being transparent to their stakeholders.

In the case of Munich Airport's IR, the reporting style moves to IR, not only integrated for the focus of corporate strategy and for diverse business. However, this combined report focuses on the expansion of the airport's infrastructure and efforts to protect the environment, fights against climate change, advance and retain employees and engage with local communities and the wider encompassing region.

\subsection{The Crucial Issues of the Materiality}

Materiality issues are the main concern for organisations to disclose in IR. This can be seen in the IR of Melia Hotel, as stated on page 11 and further explained on page 77 :

Its production was based on the results of the materiality analysis for 2013. An attempt has been made to adapt the content of the information most relevant to the Company and to its Stakeholder Groups, bearing in mind where this information is relevant (location and setting).

In 2013, and in order to reinforce the integrated reporting model, Melia proposed to its different stakeholder groups the analysis of materiality. The results can be consulted in this annual report; using the model of dialogue with stakeholder groups.

These results further support the idea of materiality discussed by Hsu et al. (2013); this explains materiality issues in IR. Materiality represents a concept deriving from financial reporting that the organisation's financial statements and investors being controlled by the economic decisions (Hsu et al., 2013). Furthermore, materiality performs a significant role to report information (Hsu et al., 2013). In addition to quantitative and qualitative aspects, materiality can fix an inaccuracy or misrepresentation of annual reviews reports (Hsu et al., 2013). 
However, it is crucial to determine the magnitudes of materiality in the aspects of external and internal standard (Hsu et al., 2013). The company should, therefore, consider disclosing the materiality criteria in accordance with 'significance to stakeholders and organization' in deciding the priority of reporting (GRI, 2011).

A different case; that of the Royal BAM Company, states that:

In BAM's aim to create an integrated approach that concentrates on matters that are critical to achieving BAM's goals and managing its impact on society, the Group has conducted a materiality assessment. Material motifs are those that substantively affect BAM's ability to create value over the short-, medium- and long-term (Royal BAM, 2014, p. 18).

The Materiality Matrix displays the prioritisation of matters based on their relative importance to BAM and to BAM's stakeholders. It should be noted that opinions of various stakeholders and appreciation in BAM's home markets may differ. Table 4 shows the high and very limited materiality concerns of Royal BAM's stakeholders.

Table 4. Materiality Components in Royal BAM

\begin{tabular}{|c|c|}
\hline \multicolumn{2}{|c|}{ Materiality Component } \\
\hline High Materiality & Very Limited Materiality \\
\hline $\begin{array}{ll}\text { - } & \text { social compliance } \\
\text { - } & \text { local communities } \\
\text { - } & \text { diversity } \\
\text { - } & \text { equal opportunity } \\
\text { - } & \text { energy emission } \\
\text { - } & \text { employee performance } \\
\text { - } & \text { waste } \\
\text { - } & \text { transparency }\end{array}$ & $\begin{array}{ll}\text { - } & \text { freedom of association } \\
\text { - } & \text { collective bargaining } \\
\text { - } & \text { labour practices grievance mechanisms } \\
\text { - } & \text { human rights assessments } \\
\text { - } & \text { supplier assessment for impacts on society } \\
\text { - } & \text { environmental compliance } \\
\text { - } & \text { equal remuneration } \\
\text { - } & \text { human rights grievance mechanisms } \\
\text { - } & \text { social public policy } \\
\text { - } & \text { grievance mechanisms for impacts on society }\end{array}$ \\
\hline
\end{tabular}

4.5 Development of New Sections

This section discusses the development of new sections being analysed by looking at sections that involve social and environment categories correspondence with the GRI G3 guidelines. According to the Table 5, as IR being introduced, the number of sections has shifted throughout the period. This change has decreased the number of sections for all companies except Uralsib, which shows no difference in the number of sections.

Regardless, the reporting content of the section titles has changed and emerges to show an adjustment with the later introduction of IR. Although sustainability information has been integrated with more sections of the later reports, IR has less variety of sections that prioritize sustainability related issues. For example, in the Uralsib reports, there is a 'Charity' section in SR, while in IR it is called 'Social Investment and Charitable Programs'. Additionally, SR includes 'Personnel Training', while IR calls this 'Personnel Management and the Internal Social Policy'. A possible explanation for this might be that the combination of financial and non-financial disclosures tends to shorten all information in one specific report. Furthermore, the company intention might be to disclose only relevant information to stakeholders. These results differ in the case of ACCA (2012), which examines annual reports and integrated reports. However, as both cases represent different phenomena, sustainability issues are raised here. Sustainability issues are driving the company to engage with their stakeholders.

Looking at different perspectives, IR is more focused on CSR sections rather than environmental aspects. For example, in the analysis of Deutsche Borse Group, sections for 'acting for climate change protection', 'social commitment' and 'education and research' are included in SR but not in IR. According to Carrol and Shabana (2010), businesses currently have sufficient power to sustain themselves, so there is no reason to wield additional power such as social and environmental power. Generally, CSR refers to company obligation to deal with their impact on the community at large and respond ethically and does not necessarily incorporate sustainability. On the other hand, sustainability concerns long-term focus and preservation of resources.

Surprisingly, Royal BAM IR found the development of new sections derived from the additional sections in the assurance part. This finding was unexpected and suggests that these procedures were intended to fulfil the rational objectives as disclosed by the company. 
Table 5. Summary of development of new sections

\begin{tabular}{lccc}
\hline & Number of & sections & $\begin{array}{c}\text { Number of Section Expand (+) } \\
\text { or Diminish(-) }\end{array}$ \\
\hline Company Name & SR & IR & -9 \\
Deutsche Borse Group & 24 & 15 & -19 \\
ENBW & 34 & 15 & -35 \\
Grupa Lotos & 68 & 33 & -2 \\
Indra, Spain & 22 & 20 & -7 \\
Munich Airport & 23 & 16 & -18 \\
Melia Hotel International & 34 & 16 & -11 \\
Novo Nordisk & 30 & 19 & -19 \\
Royal BAM Group & 44 & 25 & -8 \\
Royal DSM & 20 & 12 & 0 \\
Uralsib & 16 & 16 & $\mathbf{- 1 2 8}$ \\
Total & $\mathbf{3 1 5}$ & $\mathbf{1 8 7}$ & \\
\hline
\end{tabular}

\section{Conclusion}

\subsection{Findings and Implications}

This study has found that the majority of the ten European companies being examined disclose less SED when moving to IR. As regards integration, SEDs which matches with the GRI G3 guidelines do not appear in the main reporting. In earlier IR reports, sustainability of SED information is being reported into specific sections such as 'sustainability reports' and also mentions in the Chairman's statement. It can be seen that obvious deficiency of integration level of social and environmental information. Yet, most reports exhibited on SED were repeated with different phrasing and often exaggerated in the report. Therefore, it can be possibly justified that most of the companies' reports showing relatively less information of SED.

On the other hand, the companies might have a limited knowledge about IR's approaches. Consequently, the companies are ambiguous as to exactly what an IR 'should' include and what it 'should' look like.

Furthermore, the second analysis reviews the patterns and motifs arising from deep reading both reports, with respect to social and environmental consideration. This study found that most companies' moves to IR are driven by company strategy and regulatory requirements, reporting style, the crucial issues of materiality; and the development of new sections. As conclusions for overall patterns and motifs, the reports formulate a discussion about stakeholder accountability eloquence, focusing on investors. From the results, the report trends focus on the value of investors rather than the value of society, as mentioned in the previous literature. With regard to the analysis of section's reports (titles) solely demonstrates a particular shift in the intensity of the reports, with companies utilising more towards investor-approach titles as narratives help investors to sustain their businesses. The introduction of IR gives priority to directors to express through reporting, for example, directors' opinions about climate change, changed to reflect growing business strategy. Such a movement could demonstrate that companies try to legitimise themselves to society. Additionally, the introduction of IR seems to focus on shareholder decision making rather than society and the environment as main priorities. Although the concept of sustainability has already been embedded in IR, this does not necessarily guarantee that IR produces solely empty rhetoric as reporting will achieve its capability to alter corporate behaviour.

\subsection{Recommendations}

This study suggests that one way of improving SED in IR is to expand the information disclosed in the reports. Rather than merely repeating the same information in the reports, the way in which significant or material information is reported could be briefer, avoiding exaggerated repetition. Repeating important information in the report merely increases the quantity of SED and does not contribute an enhancement in the quality of reporting or represent more 'integrated reporting' of information. Nonetheless, the integration of SED could be increased by a number of sections in the reports to improve non-financial information within the corporate reporting.

More broadly, research is also needed to improve the quality of IR in relation to SED (all basic practices and policies) for organizations to seek the opinions of their major stakeholders that they report; these views could be included within the reports - for example, major stakeholders' views in relation to the activities incorporated in IR, such as disease (diabetes, AIDS, HIV), employee training, climate change, waste reduction and biodiversity. In turn, these would improve the new dimension of IR that is currently lacking. Additionally, this would assist companies to build an energetic integration between reporting and behaviour as IR does not want to become externally 'good' but internally 'bad' by transforming corporate behaviour in relation to social and environmental issues.

Another recommendation is for IR to include an assurance statement by an independent assurer in order for SED 
to convince investors and other stakeholder groups. This can be done by hiring assurance practices in order to secure the information to be transparent and accountable to all stakeholders including environment and community.

\subsection{Suggestions for Further Research}

It would be interesting to assess the reaction of users' views of sustainability in IR, including primary groups (investors) as well as other influential stakeholders (clients, employees, local communities, government and suppliers). The research could ask the primary group (investors) whether the reports improve companies' accountability to them as shareholders. Furthermore, investors could ask which parts of IR represent weakness to them and how to counter any problems. Eventually, further research could also relate to other stakeholders' engagement when moving from SR to IR.

Lastly, further studies could also be conducted in terms of examining the media agenda and setting theory implementation in SED, as well as whether media coverage gives good opportunities to represent positive disclosure to stakeholders.

\section{Acknowledgements}

This research gratefully acknowledges the assistance of Universiti Malaysia Sarawak by giving Myra Special Short Term Grant Scheme under [F01/SpSTG/1576/2017].

\section{References}

Abeysekera, I. (2013). A template for integrated reporting. Journal of Intellectual Capital, 14(2), 227-245, https://doi.org/10.1108/14691931311323869

Accaglobal, (2012). Integrated reporting: the influence of King III on social, ethical and environmental reporting [pdf] London: The Association of Chartered Accountant. Retrieved from http://www.accaglobal.com/content/dam/acca/global/PDF-technical/integrated-reporting/tech-tp-iirsa.pdf

Adams, C. A. (2015). Integrated Reporting Retrieved from http://drcaroladams.net/category/integrated-reporting/

Adams, C. A. (2015). The International Integrated Reporting Council: A call to action. Critical Perspectives on Accounting, 27(1), 23-28. https://doi.org/10.1016/j.cpa.2014.07.001

Adams, S., \& Simnett, R. (2011). Integrated Reporting: An Opportunity for Australia's Not-for-Profit Sector. Australian Accounting Review, 21(3), 92-301. https://doi.org/10.1111/j.1835-2561.2011.00143.x

Adams, S., Fries, J. and Simnett, R. (2011). The Journey Towards Integrated Reporting, Accountant's Digest, 558(May 2011), 1-45. https://doi.org/10.1111/j.1835-2561.2011.00143.x

Aman, A., Maelah, R., \& Auzair, S. M., 2012. Implementation of Integrated Case Studies Course for Accounting Students. Procedia - Social and Behavioral Sciences, 59(1), 9-17. https://doi.org/10.1016/j.sbspro.2012.09.239

Archel, P., Husillos, J., Larrinaga, C., \& Spence, C. (2009). Social disclosure, legitimacy theory and the role of the state. Accounting, Auditing \& Accountability Journal, 22(8), 1284-1307, https://doi.org/10.1108/09513570910999319

Atkins, J. F., Solomon, A., Norton, S., Joseph, N. L., de Villiers, C., \& de Villiers, C. (2015). The emergence of integrated private reporting, Meditari Accountancy Research, 23(1), null. https://doi.org/10.1108/medar-01-2014-0002

Bebbington, J., \& Gray, R. (2001). 'An Account of Sustainability: Failure, Success and a Reconceptualization', Critical Perspectives on Accounting, 12, 557-587. https://doi.org/10.1006/cpac.2000.0450

Bebbington, J., Unerman, J., \& O'Dwyer, B. (2014). Sustainability Accounting and Accountability. Oxon: Routledge. https://doi.org/10.4324/noe0415384889

Boedker, C., Guthrie, J., \& Cuganesan, S. (2005). An integrated framework for visualising intellectual capital. Journal of Intellectual Capital, 6(4), 510-527. https://doi.org/10.1108/14691930510628799

Brown, J., \& Dillard, J. (2014). Integrated reporting: On the need for broadening out and opening up. Accounting, Auditing \& Accountability Journal, 27(7), 1120-1156. https://doi.org/10.1108/aaaj-04-2013-1313

Buhr, N. (2007). Histories of and rationales for sustainability reporting. Sustainability Accounting and Accountability, 57-69. https://doi.org/10.4324/noe0415384889.pt2 
Busco, C., Frigo, M. L., Quattrone, P., \& Riccaboni, A. (2013). Towards integrated reporting: concepts, elements and principles. Integrated Reporting. Springer International Publishing, 3-18, https://doi.org/10.1007/978-3-319-02168-3_1

Busco, C., Frigo, M. L., Riccaboni, A., \& Quattrone, P. (2013). Integrated reporting: Concepts and cases that refine corporate accountability. New York: Springer. https://doi.org/10.1007/978-3-319-02168-3

Cheng, M., Green, W., Conradie, P., Konishi, N., \& Romi, A. (2014). The International Integrated Reporting Framework: Key Issues and Future Research Opportunities. Journal of International Financial Management \& Accounting, 25(1), 90-119. https://doi.org/10.1111/jifm.12015

De Aguiar, T. R. S., \& Bebbington, J. (2014). Disclosure on climate change: Analysing the UK ETS effects. Accounting Forum, 38(4), 227-240, https://doi.org/10.1016/j.accfor.2014.10.002

De Villiers, C., Rinaldi, L., \& Unerman, J. (2014). Integrated Reporting: Insights, gaps and an agenda for future research. Accounting, Auditing \& Accountability Journal, 27(7), 1042-1067, https://doi.org/10.1108/aaaj-06-2014-1736

Deegan, C. (2002). Introduction. Accounting, Auditing \& Accountability Journal, 15(3), 282-311, https://doi.org/10.1108/09513570210435852

Deegan, C. (2007). Organizational legitimacy as a motive for sustainability reporting. Sustainability Accounting and Accountability, 127-149. https://doi.org/10.4324/noe0415384889.ch7

Deegan, C., Rankin, M., \& Voight, P. (2000). Firm's Disclosure Reactions to Major Social Incidents: Australian Evidence. Accounting Forum, 24(1), 101-130. https://doi.org/10.1111/1467-6303.00031

Deutsche Borse Group. (2012). Corporate Reports. Retrieved from https://deutsche-boerse.com/dbg/dispatch/en/binary/gdb_content_pool/imported_files/public_files/10_down loads/12_db_annual_reports/2012/Annual_Report_2012.pdf

Duff, A. (2011). Big four accounting firms' annual reviews: A photo analysis of gender and race portrayals. Critical Perspectives on Accounting, 22(1), 20-38. https://doi.org/10.1016/j.cpa.2010.05.001

Eccles, R. G., \& Armbrester, K. (2011). Integrated Reporting in the Cloud: Two Disruptive Ideas Combined. IESE Insight, 8, 13-20. https://doi.org/10.15581/002.art-1890

Eccles, R. G., \& Krzus, M. (2010). One Report: Integrated Reporting for a Sustainable Strategy, Wiley: New York. https://doi.org/10.1002/9781119199960

Eccles, R. G., \& Serafeim, G. (n.d.). Corporate and integrated reporting: A functional perspective. Corporate Stewardship: Achieving Sustainable Effectiveness, 156-172, https://doi.org/10.9774/gleaf.9781783532605_10

Eden, S. E. (1994). Using sustainable development, The business case. Global Environmental Change, 4(2), 160-167. https://doi.org/10.1016/0959-3780(94)90050-7

Ernst \& Young Global Limited. (2013). EY's Excellence in Integrated Reporting Awards 2013: A survey of integrated reports from South Africa's top 100 JSE listed companies and top 10 state owned companies. (EYGM Limited: London), https://doi.org/10.22495/rgcv7i3p3

EY. (2012). Ernst \& Young's excellent in integrated reporting awards 2012 (EYGM Limited: London).

EY. (2014). EY's excellence in integrated reporting awards 2014: A survey of integrated reports from South Africa's top 100 JSE-listed companies and top 10 state-owned companies (Ernst \& Young Global Limited: London).

Flower, J. (2015). The International Integrated Reporting Council: A story of failure. Critical Perspectives on Accounting, 27, 1-17, https://doi.org/10.1016/j.cpa.2014.07.002

Frias-Aceituno, J. V., Rodriguez-Ariza, L., \& Garcia-Sanchez, I. (2012). The Role of the Board in the Dissemination of Integrated Corporate Social Reporting. Corporate Social Responsibility and Environmental Management, 20(4), 219-233, https://doi.org/10.1002/csr.1294

Frias-Aceituno, J. V., Rodríguez-Ariza, L., \& Garcia-Sánchez, I. M. (2012). Explanatory Factors of Integrated Sustainability and Financial Reporting. Business Strategy and the Environment, 23(1), 56-72, https://doi.org/10.1002/bse.1765

Frías-Aceituno, J. V., Rodríguez-Ariza, L., \& García-Sánchez, I. M. (2013). Is integrated reporting determined by a country's legal system? An exploratory study. Journal of Cleaner Production, 44(1), 45-55, 
https://doi.org/10.1016/j.jclepro.2012.12.006

García-Sánchez, I. M., Rodríguez-Ariza, L., \& Frías-Aceituno, J. V. (2013). The cultural system and integrated reporting. International Business Review, 22(5), 828-838, https://doi.org/10.1016/j.ibusrev.2013.01.007

Gomes, S. F., Eugénio, T. C. P., \& Branco, M. C. (2015). Sustainability reporting and assurance in Portugal. Corporate Governance. The International Journal of Business in Society, 15(3), 281-292, https://doi.org/10.1108/cg-07-2013-0097

Gray, R., Adams, C. A., \& Owen, D. (2013). Accountability, Social Responsibility and Sustainability: Accounting for Society and the Environment. Harlow: Pearson, https://doi.org/10.1108/sampj-04-2015-0021

GRI. (2011). G3 and G3.1 Guidelines. Retrieved July 13, 2015 from https://www.globalreporting.org/resourcelibrary/G3-Guidelines-Incl-Technical-Protocol.pdf

GRI. (2011). GRI Resource Library. Technical Protocol Applying the Report Content Principles. Retrieved July 13, 2015 from https://www.globalreporting.org/resourcelibrary/GRI-Technical-Protocol.pdf

GRI. (2011). GRI Resource Library. The sustainability content of integrated reports - a survey of pioneers. Retrieved July 14, 2015 from https://www.globalreporting.org/resourcelibrary/GRI-IR.pdf

GRI. (2014). Global Reporting Policy and Regulation. Retrieved August 18, 2015 from https://www.globalreporting.org/information/policy/Pages/EUpolicy.aspx

GRI. (2014). Global Reporting Resource Library. Retrieved August 18, 2015 from https://www.globalreporting.org/resourcelibrary/GRI-An-introduction-to-G4.pdf

GRI. (2015). Global Reporting News. Retrieved August 12, 2015 from https://www.globalreporting.org/information/events/conference2013/news/Pages/Updates/1-2.aspx

Haller, A., \& van Staden, C. (2014). The value added statement - an appropriate instrument for Integrated Reporting. Accounting. Auditing \& Accountability Journal, 27(7), 1190-1216, https://doi.org/10.1108/aaaj-04-2013-1307

Higgins, C., Stubbs, W., \& Love, T. (2014). Walking the talk(s): Organisational narratives of integrated reporting. Accounting. Auditing \& Accountability Journal, 27(7), 1090-1119, https://doi.org/10.1108/aaaj-04-2013-1303

Hindley, T., \& Buys, P. W. (2012). Integrated Reporting Compliance With The Global Reporting Initiative Framework: An Analysis Of The South African Mining Industry. International Business \& Economics Research Journal (IBER), 11(11), 1249. https://doi.org/10.19030/iber.v11i11.7372

Hsu, C. W., Lee, W. H., \& Chao, W. C. (2013). Materiality analysis model in sustainability reporting: a case study at Lite-On Technology Corporation. Journal of Cleaner Production, 57, 142-215, https://doi.org/10.1016/j.jclepro.2013.05.040

IIRC. (2012). The Pilot Programme Year Book 2013: Business and Investors Explore the Sustainability Perspective of Integrated Reporting. Retrieved August 14, 2015 from http://www.theiirc.org/wp-content/uploads/2013/12/IIRC-PP-Yearbook-2013_PDF4_PAGES.pdf

IIRC. (2015). Integrated Reporting News. Retrieved July 10, 2015 from http://integratedreporting.org/news/only-10-of-companies-are-prepared-for-non-financial-reporting-directiv es-are-you

Ioana, D., \& Adriana, T. T. (2013). New corporate reporting trends. Analysis on the evolution of integrated reporting. Annals of the University of Oradea. Economic Science Series, 22(1), 1221-1228, https://doi.org/10.1007/978-3-642-37620-7_2

Isaksson, R., \& Steimle, U. (2009). What does GRI - reporting tell us about corporate sustainability? The TQM Journal, 21(2), 168-181. https://doi.org/10.1108/17542730910938155

Islam, M. A., \& Deegan, C. (2010). Media pressures and corporate disclosure of social responsibility performance information: A study of two global clothing and sports retail companies. Accounting and Business Research, 40(2), 131-148. https://doi.org/10.1080/00014788.2010.9663388

Jensen, J. C., \& Berg, N. (2011). Determinants of Traditional Sustainability Reporting Versus Integrated Reporting. An Institutionalist Approach. Business Strategy and the Environment, 21(5), 299-316, https://doi.org/10.1002/bse.740

Knauer, A., \& Serafeim, G. (2014). Attracting Long-Term Investors Through Integrated Thinking and Reporting: 
A Clinical Study of a Biopharmaceutical Company. Journal of Applied Corporate Finance, 26(2), 57-64, https://doi.org/10.1111/jacf.12067

Knebel, S., \& Seele, P. (2015). Quo vadis GRI? A (critical) assessment of GRI 3.1 A+ non-financial reports and implications for credibility and standardization. Corporate Communications: An International Journal, 20(2), 196-212, https://doi.org/10.1108/ccij-11-2013-0101

Kolk, A., \& Perego, P. (2008). Determinants of the adoption of sustainability assurance statements: an international investigation. Business Strategy and the Environment, 19(3), 182-198. https://doi.org/10.1002/bse.643

KPMG. (2012). Integrated reporting: Performance insight through better business reporting (Issue 2) (KPMG International Cooperative: London). Retrieved August 14, 2015 from https://assets.kpmg.com/content/dam/kpmg/pdf/2011/10/Integrated-Reporting-ENG.pdf

Livesey, S. M. (2001). Eco-Identity as Discursive Struggle: Royal Dutch/Shell, Brent Spar, and Nigeria. Journal of Business Communication, 38(1), 58-91, https://doi.org/10.1177/002194360103800105

Livesey, S. M. (2002). The Discourse of the Middle Ground. Management Communication Quarterly, 15(3), 313-349. https://doi.org/10.1177/0893318902153001

Lodhia, S. (2014). Exploring the Transition to Integrated Reporting Through a Practice Lens: An Australian Customer Owned Bank Perspective. Journal of Business Ethics, 129(3), 585-598, https://doi.org/10.1007/s10551-014-2194-8

Mathews, R. (2004). Developing a matrix approach to categorise the social and environmental accounting research literature. Qualitative Research in Accounting \& Management, 1(1), 30-45, https://doi.org/10.1108/11766090410816280

McNair-Connolly, C. J., Silvi, R., \& Bartolini, M. (2013). Integrated Reporting and Value-Based Cost Management: A Natural Union. Integrated Reporting, 147-157, https://doi.org/10.1007/978-3-319-02168-3_9

Melia Hotel International. (2013) Annual Report and CSR. Retrieved July 21, 2015 from http://www.meliahotelsinternational.com/sites/default/files/informes-financieros/Informe $\% 20$ Anual $\% 20 \% 2$ 6\%20RSC\%202013\%20MHI_en.pdf

Melloni, G. (2015). Intellectual capital disclosure in integrated reporting: an impression management analysis. Journal of Intellectual Capital, 16(3), 661-680. https://doi.org/10.1108/jic-11-2014-0121

Merkl-Davies, D. M., Brennan, N. M., \& Vourvachis, P. (2011). Text Analysis Methodologies in Corporate Narrative Reporting Research' (paper presented at 23rd CSEAR International Colloquium, St Andrews, September), null. https://doi.org/10.2139/ssrn.2296793

Monfreda, C., Wackernagel, M., \& Deumling, D. (2004). Establishing national natural capital accounts based on detailed Ecological Footprint and biological capacity assessments. Land Use Policy, 21(3), 231-246, https://doi.org/10.1016/j.landusepol.2003.10.009

Novo Nordisk. (2004). Corporate Reports. Retrieved July 21, 2015 from http://www.novonordisk.com/content/dam/Denmark/HQ/Sustainability/documents/novo-nordisk-annual-rep ort-2004.pdf

Owen, D., Gray, R., \& Bebbington, J. (1997). Green Accounting: Cosmetic Irrelevance or Radical Agenda for Change? Asia-Pacific Journal of Accounting, 4(2), 175-198, https://doi.org/10.1080/10293574.1997.10510519

Parrot, K. W., \& Tierney, B. X. (2012). Integrated Reporting, Stakeholder Engagement, and Balanced Investing at American Electric Power. Journal of Applied Corporate Finance, 24(2), 27-37, https://doi.org/10.1111/j.1745-6622.2012.00375.x

Patten, D. M. (2014). Accounting for Public Interest. Advances in Business Ethics Research. Available at: link.springer.com Retrieved March 2, 2015 from http://link.springer.co.uk

Perego, P., \& Kolk, A. (2012). Multinationals' Accountability on Sustainability: The Evolution of Third-party Assurance of Sustainability Reports. Journal of Business Ethics, 110(2), 173-190, https://doi.org/10.1007/s10551-012-1420-5

Rensburg, R., \& Botha, E. (2014). Is Integrated Reporting the silver bullet of financial communication? A 
stakeholder perspective from South Africa. Public Relations Review, 40(2), 144-152, https://doi.org/10.1016/j.pubrev.2013.11.016

Reuter, M., \& Messner, M. (2015). Lobbying on the integrated reporting framework. Accounting, Auditing \& Accountability Journal, 28(3), 365-402, https://doi.org/10.1108/aaaj-03-2013-1289

Royal BAM. (2014). Corporate Reports. Retrieved July 21, 2015 from http://www.bam.eu/sites/default/files/domain-106/documents/bam-2014-integrated-report-106-1426072428 125962623.pdf

Serafeim, G. (2014). Integrated Reporting and Investor Clientele. SSRN Electronic Journal. https://doi.org/10.2139/ssrn.2378899

Stent, W., \& Dowler, T. (2015). Early assessments of the gap between integrated reporting and current corporate reporting. Meditari Accountancy Research, 23(1), 92-117. https://doi.org/10.1108/medar-02-2014-0026

Stubbs, W., \& Higgins, C. (2014). Integrated Reporting and internal mechanisms of change. Accounting, Auditing \& Accountability Journal, 27(7), 1068-1089, https://doi.org/10.1108/aaaj-03-2013-1279

Stubbs, W., \& Higgins, C. P. (2013). Exploring the inhibitors and enablers of Integrated Reporting in Australia. Academy of Management Proceedings, 2013(1), 13116-13116, https://doi.org/10.5465/ambpp.2013.13116abstract

Thomson, I. (2015). "But does sustainability need capitalism or an integrated report" a commentary on "The International Integrated Reporting Council: A story of failure" by Flower, J. Critical Perspectives on Accounting, 27, 18-22. https://doi.org/10.1016/j.cpa.2014.07.003

UNEP (United Nation Environmental program, GRI, KPMG, Unit for CG in Africa. (2013). Carrots and Sticks Sustainability reporting policies worldwide - today's best practice, tomorrow's trends. Retrieved July 17, 2015 from https://www.globalreporting.org/resourcelibrary/Carrots-and-Sticks.pdf

Unepfi. (2011). Unepfi publications. Retrieved August 18, 2015 from http://www.unepfi.org/fileadmin/publications/property/Brief_Integrated_Reporting_Pilot_Programme3.pdf

\section{Copyrights}

Copyright for this article is retained by the author(s), with first publication rights granted to the journal.

This is an open-access article distributed under the terms and conditions of the Creative Commons Attribution license (http://creativecommons.org/licenses/by/4.0/). 